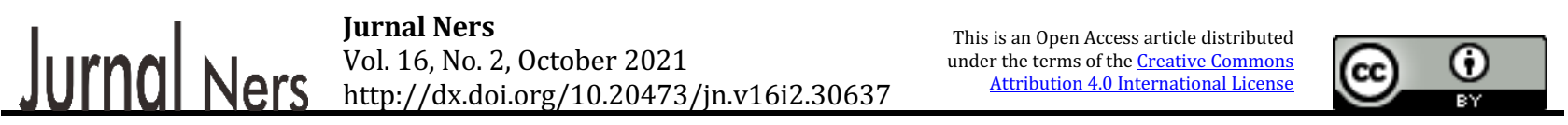

Original Research

\title{
Parents' Psychological Aspect in Caring for the Child During COVID-19 Pandemic
}

\section{Hasinuddin ${ }^{1}$, Rusana Rusana ${ }^{2}$, Ulva Noviana ${ }^{1}$, Heni Ekawati ${ }^{1}$, Nurul Aini $^{3}$ and Sandeep Poddar 4}

1STIKES Ngudia Husada Madura, Madura, Indonesia

${ }^{2}$ STIKES Al-Irsyad Al-Islamiyyah Cilacap, Cilacap Indonesia

3Universitas Muhammadiyah Malang, Malang, Indonesia

${ }^{4}$ Lincoln University College, Selangor, Malaysia

\begin{abstract}
Introduction: COVID-19 is unprecedented, especially for parents with children aged 2-12 years old who are prone to infection due to their activities. The psychological condition of parents will be affected as they are worried about their children being infected with COVID-19.
\end{abstract}

Methods: This study aims to identify and analyse the psychological aspects of parents who are caring for children during the COVID-19 pandemic.

Results: The results showed that as many as 236 parents $(80.9 \%)$ showed an emotional anxiety response. The social reaction to the COVID-19 situation was more likely to be a positive response $(73.8 \%)$ rather than a negative response.

Conclusion: The reactions that occur in parents who have pre-school and school-aged children regarding the COVID-19 were anxiety and worry. Reactions arise due to the information obtained being less verifiable, namely social media.

\section{ARTICLE HISTORY}

Received: October 12, 2021

Accepted: December 16, 2021

\section{KEYWORDS}

child; caring; pandemic; psychosocial; parent

\section{CONTACT}

M. Hasinuddin

$\bowtie \underline{\text { hasin3333.nhm@gmail.com }}$

$\fallingdotseq$ STIKES Ngudia Husada

Madura, Madura, Indonesia

Cite this as: Hasinuddin, M., Rusana, R., Noviana, U., Ekawati, H., Aini, N., \& Poddar, S. (2021). Parents' Psychological Aspect in Caring for The Child During Covid-19 Pandemic. Jurnal Ners, 16(2). 193-197. doi:http://dx.doi.org/10.20473/jn.v16i2.30637

\section{INTRODUCTION}

The World Health Organization (WHO) has reported more than 2 million cases of Corona Virus Disease (COVID-19) in more than 210 countries and regions, resulting in 195,755 people dying and 781,109 people recovering (Bhattacharya et al., 2020; Nakoe et al., 2020). In Indonesia, two cases of confirmed COVID-19 were announced in March 2020, and it increased significantly to reach 1790 confirmed cases, in which there were 113 new cases per day, with 170 deaths, and 112 people recovered (Djalante et al., 2020; Ministry of Health, 2020). The unpredicted COVID-19 situation has created stress, and it is likely to affect people (World Health Organization, 2020), especially parents caring for children in the school-aged group (Brown et al., 2020; Moscardino et al., 2021). A previous study has proven that the COVID-19 emergency resulted in a worrying period for families, increasing difficulties in managing daily activities, especially free time and structured activities (Colizzi et al., 2020). Since the phenomenon of the COVID-19 pandemic affects people's psychological and daily lives (Buzzi et al., 2020), family living conditions suddenly change in the home environment, and, thus, the role of parents' education for children is more important than ever. Children expect parents who can provide support and pay attention to their development and provide new learning experiences, especially for toddlers and pre-schoolers (Jiao et al., 2020). Many parents also have to work from home, so managing time to work and accompanying children becomes very problematic. This situation can significantly increase the risk of experiencing stress and negative emotions in parents, with the effect of decreasing the welfare of children (Sprang \& Silman, 2013). 
The psychological wellbeing of parents and children is a major concern with the quarantine regulation due to COVID-19. This creates fear and anxiety in both parents and children (Liu et al., 2020). Most of the studies conducted during the pandemic and since the beginning of the COVID-19 outbreak examined the psychological consequences on the general population, especially on the elderly and children (Brooks et al., 2020). A survey in China found that the psychological effects on children during the COVID-19 pandemic, such as fear, inattention and irritability, were the most severe symptoms (Jiao et al., 2020).

Several factors influence the psychological response of parents and children including structural aspects of the home and family as well as the environment. The subjective experience of parents, stress and adjustment to quarantine, affect the welfare of parents and children which can make parents stressed and can interfere with children's wellbeing (Abidin, 1992; Madigan et al., 2018; Wong et al., 2021). The COVID-19 pandemic increases the psychological problems of parents, especially stress at the individual and community level, which has a negative impact on the emotional wellbeing and behavior of children and parents (Dalton et al., 2020). This study aims to identify and analyse the psychological aspects of parents who are caring for children during the COVID-19 pandemic.

\section{MATERIALS AND METHODS}

A cross-sectional approach was used in this study. The samples were taken by purposive sampling technique which consisted of parents or guardian with children aged 2-12 years as many as 325 people, from more than seven provinces in Indonesia. The inclusion criteria of the participants in this study were: (1) parents or guardians who have children in aged 2-12 years old; (2) living together with the children and caring for them; (3) being able to fill in the Google Form; and (4) agreeing with the terms and conditions of this research. Meanwhile, those who were not eligible for the inclusion criteria will be excluded from this study. The dependent variable of this study was parents' psychological aspects and caring for children in the school age group was the independent variable.

The data were collected online in July 2020 by utilising Google Forms as a tool to distribute the questionnaire. We reached the participants through WhatsApp groups by sharing the Google Form link. The questionnaire instrument contains the characteristics, beliefs and sources of information as well as the psychosocial (emotional and social) responses of the respondents.

The used instrument in this study was a questionnaire which was developed from the instrument protocol from Health Department ((Kemenkes, 2020). Several questions were directed to measure the socio-demography of participants, in particular: Child's Age, Child's Gender, Origin,
Table 1. Characteristics of respondents $(\mathrm{N}=325)$

\begin{tabular}{|c|c|c|}
\hline Characteristic & $\mathbf{n}$ & $\%$ \\
\hline \multicolumn{3}{|l|}{ Child's age: } \\
\hline Toddler & 202 & 62.2 \\
\hline School Age & 123 & 37.8 \\
\hline \multicolumn{3}{|l|}{ Child's Gender: } \\
\hline Male & 173 & 53.2 \\
\hline Female & 152 & 46.8 \\
\hline \multicolumn{3}{|l|}{ Origin: } \\
\hline East Java & 230 & 70.8 \\
\hline Central Java & 36 & 11.1 \\
\hline West Java & 26 & 8.0 \\
\hline Jakarta & 9 & 2.8 \\
\hline Bali & 9 & 2.8 \\
\hline DIY & 4 & 1.2 \\
\hline South Sumatera & 3 & 0.9 \\
\hline The other & 8 & 2.4 \\
\hline \multicolumn{3}{|l|}{ Parent Status: } \\
\hline Parents (Mother or Father) & 319 & 98.2 \\
\hline Another Guardian & 6 & 1.8 \\
\hline \multicolumn{3}{|l|}{ The belief of COVID-19 Existence } \\
\hline Believe & 307 & 94.5 \\
\hline Do not believe & 18 & 5.5 \\
\hline \multicolumn{3}{|l|}{ Information Source: } \\
\hline Social Media & 249 & 76.6 \\
\hline Health Worker & 76 & 23.4 \\
\hline \multicolumn{3}{|c|}{ Psychological Response/ Emotional: } \\
\hline Unconcern & 62 & 19.1 \\
\hline Anxiety & 263 & 80.9 \\
\hline \multicolumn{3}{|l|}{ Social Response: } \\
\hline Positive & 240 & 73.8 \\
\hline Negative & 85 & 26.2 \\
\hline
\end{tabular}

Parental Status. Specific questions related to the psychological response were (1) the belief of COVID19 existence divided into two categories: believe and do not believe; (2) Information Resource consisted two options: social media and health worker; (3) Psychological Response or emotion was measured into unconcern and anxiety; and (4) Social Response included positive and negative.

Data were analysed by univariate analysis, bivariate with Chi-square and multivariate using linear regression. All data analysis was performed statistically using SPSS version 26 for Windows (SPSS, Inc, Chicago, Ill) and significance was set at $\mathrm{p}<0.05$.

The research has been approved by the research ethics committee of STIKES Ngudia Husada Madura (681/KEPK/STIKES-NHM/EC/VII/2020) on July, 23rd 2020.

\section{RESULTS}

Most of the respondents were mothers (88.0\%), from East Java (70.8\%), which was classified as the red zone for the spread of COVID-19. The majority of participants believed in the existence of COVID-19 (94.5\%), sources of information about COVID-19 were from social media (42.8\%). Respondents in this study had children of pre-school age (44.3\%) with sex mostly male (53.2\%). Most of the respondents were likely to have experienced psychological responses 
(anxiety) (80.9\%) rather than unconcern response (19.1\%). Social response to the COVID-19 situation was more likely to be positive response $(73.8 \%)$ than negative response (26.2\%). Detailed information about the characteristics of respondents is depicted in Table 1.

The analysis of the relationship between parental status and respondent's belief with psychological responses showed that there were $261(81.8 \%)$ and 258 (84\%) participants who experienced an anxiety emotional response, worried that a family member had contracted COVID-19. The results of statistical tests showed that there was a significant relationship between parental status and respondents' psychological responses ( $p$-value $=0.014$ ) as depicted in Table 2. In addition, the belief of COVID-19 existence showed a significant value among parents who believe compared to those who do not believe ( $p$ value $=0.001)$.

\section{DISCUSSION}

The COVID-19 situation has been a stressor for families as the disease is creating uncertainty and novelty (Brown et al., 2020; Chung et al., 2020). The life condition of families has been restricted and led to experience some stressors and emotional feelings (Morelli et al., 2020). The stressors come from several factors including managing children for 24 hours, having had to work from home, the reduction of wages and the fear of COVID-19 infection (Morelli et al., 2020; Spinelli et al., 2020). These impacts influence the family system and stimulate parenting stress; even those who are not exposed to the virus can feel the indirect effect of the COVID-19 pandemic (Bavel et al., 2020; Chung et al., 2020). Our study proved that two psychological factors (parental status and the belief of COVID-19 existence) have shown a significant association with the parental condition when caring for their children during the pandemic.

The status of parents is highly likely to have an association with the psychological state of parents caring for their children $\left(\mathrm{p}=0.014 ; \mathrm{X}^{2}=83\right)$ in which most parents felt anxiety about the exposure of children to the COVID-19 virus. This finding has correlation with a previous study that most of parents reported high level of anxiety of COVID-19 infecting their children when they do physical outdoors activities (McCormack et al., 2020). The parents' anxiety encouraged them to make some restrictions for their children, particularly limited access to the public areas, and this drove the parents to follow the health recommendations, such as physical distancing (Tremblay et al., 2016). Long-term effect of the parents' anxiety is the child's boredom and the desire to get out of the house, which triggers the parents to be more frustrated in caring for them. Then, this situation will turn into a family stress and harsh parenting. To prevent the forecast stress situation, it is better for the parents to manage their psychological care by balancing the way they handle their anxiety about the situation and their children's wellbeing. The role of health practitioners is needed to be a consultant for the parents on how to cope with this situation.

The second significant factor is the parents' perception about the existence of COVID-19 itself. In present study, we evaluate that the more parents believe about the COVID-19 pandemic, the more they felt worry about the disease. Generally, the COVID-19 pandemic has a psychological effect and becomes a heavy stressor. A common response in times of crisis is anxiety which arises because of fear or feeling uncomfortable. Anxiety about the spread of COVID-19 can happen to parents as they hear news or information related to the increasingly rapid spread of the Corona virus and the increasing number of

Table 2. The Relationship between Respondent Status and the Psychological (Emotional and Social) Response of Parents during the COVID-19 Pandemic (N=325)

\begin{tabular}{|c|c|c|c|c|}
\hline \multirow[b]{2}{*}{ Variables } & \multicolumn{2}{|c|}{ Psychological Response (Emotional) } & \multirow[b]{2}{*}{$\mathbf{X}^{2}$} & \multirow[b]{2}{*}{ p-value } \\
\hline & $\begin{array}{c}\text { Unconcern } \\
\text { n (\%) }\end{array}$ & $\begin{array}{c}\text { Anxiety } \\
\text { n (\%) }\end{array}$ & & \\
\hline \multicolumn{5}{|l|}{ Child's Gender: } \\
\hline Male & $35(20.2 \%)$ & $138(79.8 \%)$ & 1.174 & 0.672 \\
\hline Female & $27(17.8 \%)$ & $125(82.2 \%)$ & & \\
\hline \multicolumn{5}{|l|}{ Parental Status: } \\
\hline Parent & $58(18.2 \%)$ & $261(81.8 \%)$ & 0.111 & $0.014^{*}$ \\
\hline Another Guardian & $4(66.7 \%)$ & $2(33.3 \%)$ & & \\
\hline \multicolumn{5}{|l|}{ Child's Age: } \\
\hline Toddlers & $33(16.3 \%)$ & $169(83.7 \%)$ & 0.633 & 0.143 \\
\hline Pre-School & $29(23.6 \%)$ & $94(76.4 \%)$ & & \\
\hline \multicolumn{5}{|c|}{ The belief of COVID-19 Existence: } \\
\hline Believe & $49(16 \%)$ & $258(84.0 \%)$ & 0.073 & $0.001^{*}$ \\
\hline Do Not Believe & $13(72.2 \%)$ & $5(27.8 \%)$ & & \\
\hline \multicolumn{5}{|l|}{ Information Source } \\
\hline Social Media & 48 (19.3\%) & $201(80.7 \%)$ & 1.058 & 1.000 \\
\hline Health Worker & $14(18.4 \%)$ & $62(81.6)$ & & \\
\hline
\end{tabular}


patients. A qualitative study stated that participants were afraid of contracting COVID-19 both for themselves and their families (Sumakul \& Ruata, 2020). Another study has also proved that the anxiety of COVID-19 tends to make people feel fear and the common concern of the fear is because of the health condition of their loved ones (Mertens et al., 2020).

The gender of children has not shown any significant relevance with the psychological parents in caring for their children during the pandemic. Theoretically, the gender of children influences the way parents treat, communicate and behave to the children by which the tendency is to be more protective to a girl than boy (Mascaro et al., 2017). From this phenomenon, we can assume that under some circumstances, such as crisis and pandemic, the psychological effect on parents, specifically the anxiety feeling, will equally appear both for sons and daughters. Aside from gender, the age of children was also not considered as a factor related to the psychological state of parents. The parents showed the same psychological response when caring for toddlers and school age children. The reason for this is because parents and children have a strong inner and emotional connection. Thus, parents will feel more worried if their child is sick or contracted with a disease regardless how old their children are.

According to the information source, this study confirmed that there is no relationship between the psychological status of parents with how the get to know the information about COVID-19. In fact, various information about COVID-19 has spread massively from various media rather other sources (Ahmadi et al., 2021; Prasetyawati et al., 2021). Social media through electronic media presents various kinds of news, both actual, trusted and hoax news or information. Fake news or hoax news is news that is spread by certain parties with various interests. There are several factors that make a person or group believe in the spread of hoax news, especially about the trending COVID-19. The factors in question are limited knowledge and if the news is in accordance with the opinion of the recipient or reader (Chumairoh, 2020).

\section{CONCLUSION}

The psychological state of parents caring for children during COVID-19 pandemic has been correlated by two factors: the parental status and the belief of COVID-19 existence. The reactions that occur in parents who have pre-school and school-aged children regarding COVID-19 are anxiety and worry. This study suggests that managing the psychological health of parents is essential while caring for children during a crisis situation, such as a pandemic since it will correlate with the parenting pattern and can prevent harsh parenting. It is a must for health practitioners to provide psychological education sessions for the parents about how to cope with the stressors when caring for children in a pandemic situation.

\section{REFERENCES}

Abidin, R. R. (1992). The Determinants of Parenting Behavior. Journal of Clinical Child Psychology, 21(4), 407-412. https://doi.org/10.1207/s15374424jccp2104_12

Ahmadi, M. I., Gustian, D., \& Sembiring, F. (2021). Analisis Sentiment Masyarakat terhadap Kasus Covid-19 pada Media Sosial Youtube dengan Metode Naive bayes Jumlah kasus Aktif. Jurnal Sains Komputer \& Informatika (J-SAKTI), 5(September), 807-814. https://doi.org/http://dx.doi.org/10.30645/jsakti.v5i2.378

Bavel, J. J. V., Baicker, K., Boggio, P. S., Capraro, V., Cichocka, A., Cikara, M., Crockett, M. J., Crum, A. J., Douglas, K. M., Druckman, J. N., Drury, J., Dube, O., Ellemers, N., Finkel, E. J., Fowler, J. H., Gelfand, M., Han, S., Haslam, S. A., Jetten, J., ... Willer, R. (2020). Using social and behavioural science to support COVID-19 pandemic response. In Nature Human Behaviour (Vol. 4, Issue 5, pp. 460-471). https://doi.org/10.1038/s41562-020-0884-z

Bhattacharya, S., Basu, P., \& Poddar, S. (2020). Changing epidemiology of SARS-CoV in the context of COVID-19 pandemic. Journal of Preventive Medicine and Hygiene, 61(2), E130E136. https://doi.org/10.15167/24214248/jpmh2020.61.2.1541

Brooks, S. K., Webster, R. K., Smith, L. E., Woodland, L., Wessely, S., Greenberg, N., \& Rubin, G. J. (2020). The psychological impact of quarantine and how to reduce it: rapid review of the evidence. In The Lancet (Vol. 395, Issue 10227, pp. 912-920). https://doi.org/10.1016/S0140-6736(20)304608

Brown, S. M., Doom, J. R., Lechuga-Peña, S., Watamura, S. E., \& Koppels, T. (2020). Stress and parenting during the global COVID-19 pandemic. Child Abuse and Neglect, 110. https://doi.org/10.1016/j.chiabu.2020.104699

Buzzi, C., Tucci, M., Ciprandi, R., Brambilla, I., Caimmi, S., Ciprandi, G., \& Marseglia, G. L. (2020). The psycho-social effects of COVID-19 on Italian adolescents 'attitudes and behaviors. 4-11.

Chumairoh, H. (2020). Ancaman Berita Bohong di Tengah Pandemi Covid-19. Vox Populi, 3(1), 22. https://doi.org/10.24252/vp.v3i1.14395

Chung, G., Lanier, P., \& Wong, P. Y. J. (2020). Mediating Effects of Parental Stress on Harsh Parenting and Parent-Child Relationship during Coronavirus (COVID-19) Pandemic in Singapore. Journal of Family Violence. https://doi.org/10.1007/s10896-020-00200-1

Colizzi, M., Sironi, E., Antonini, F., Ciceri, M. L., Bovo, C., \& Zoccante, L. (2020). brain sciences Psychosocial and Behavioral Impact of COVID-19 in Autism Spectrum Disorder: An Online Parent Survey. Brain Sciences Journal, 10(341), 1-15. https://doi.org/doi:10.3390/brainsci10060341

Dalton, L., Rapa, E., \& Stein, A. (2020). Protecting the psychological health of children through effective 
communication about COVID-19. In The Lancet Child and Adolescent Health (Vol. 4, Issue 5, pp. 346-347). https://doi.org/10.1016/S23524642(20)30097-3

Djalante, R., Lassa, J., Setiamarga, D., Sudjatma, A., Indrawan, M., Haryanto, B., Mahfud, C., Sinapoy, M. S., Djalante, S., Rafliana, I., Gunawan, L. A., Surtiari, G. A. K., \& Warsilah, H. (2020). Review and analysis of current responses to COVID-19 in Indonesia: Period of January to March 2020. Progress in Disaster Science, https://doi.org/10.1016/j.pdisas.2020.100091

Jiao, W. Y., Wang, L. N., Liu, J., Fang, S. F., Jiao, F. Y., Pettoello-Mantovani, M., \& Somekh, E. (2020). Behavioral and Emotional Disorders in Children during the COVID-19 Epidemic. In Journal of Pediatrics (Vol. 221, pp. 264-266.e1). https://doi.org/10.1016/j.jpeds.2020.03.013

Kemenkes. (2020). Protokol Dukungan Kesehatan Jiwa dan Psikosial (DKJPS) Anak dan Remaja pada Masa. Kementerian Kesehatan Republik Indonesia.

Liu, J. J., Bao, Y., Huang, X., Shi, J., \& Lu, L. (2020). Mental health considerations for children quarantined because of COVID-19. In The Lancet Child and Adolescent Health (Vol. 4, Issue 5, pp. 347-349). https://doi.org/10.1016/S23524642(20)30096-1

Madigan, S., Oatley, H., Racine, N., Fearon, R. M. P., Schumacher, L., Akbari, E., Cooke, J. E., \& Tarabulsy, G. M. (2018). A Meta-Analysis of Maternal Prenatal Depression and Anxiety on Child Socioemotional Development. In Journal of the American Academy of Child and Adolescent Psychiatry (Vol. 57, Issue 9, pp. 645-657.e8). https://doi.org/10.1016/j.jaac.2018.06.012

Mascaro, J. S., Rentscher, K. E., Hackett, P. D., Mehl, M. R., \& Rilling, J. K. (2017). Child gender influences paternal behavior, language, and brain function. Behavioral Neuroscience, 131(3), 262-273. https://doi.org/10.1037/bne0000199

McCormack, G. R., Doyle-Baker, P. K., Petersen, J. A., \& Ghoneim, D. (2020). Parent anxiety and perceptions of their child's physical activity and sedentary behaviour during the COVID-19 pandemic in Canada. Preventive Medicine Reports, 20.

https://doi.org/10.1016/j.pmedr.2020.101275

Mertens, G., Gerritsen, L., Duijndam, S., Salemink, E., \& Engelhard, I. M. (2020). Fear of the coronavirus (COVID-19): Predictors in an online study conducted in March 2020. Journal of Anxiety Disorders,

74. https://doi.org/10.1016/j.janxdis.2020.102258

Ministry of Health. (2020). COVID-19 Situation.

Morelli, M., Cattelino, E., Baiocco, R., Trumello, C., Babore, A., Candelori, C., \& Chirumbolo, A. (2020). Parents and Children During the COVID-19 Lockdown: The Influence of Parenting Distress and Parenting Self-Efficacy on Children's Emotional Well-Being. Frontiers in Psychology, 11. https://doi.org/10.3389/fpsyg.2020.584645

Moscardino, U., Dicataldo, R., Roch, M., Carbone, M., \& Mammarella, I. C. (2021). Parental stress during COVID-19: A brief report on the role of distance education and family resources in an Italian sample. Current Psychology, 40(11), 5749-5752. https://doi.org/10.1007/s12144-021-01454-8

Nakoe, R., S Lalu, N. A., \& Mohamad, Y. A. (2020). Perbedaan Efektivitas Hand-Sanitizer Dengan Cuci Tangan Menggunakan Sabun Sebagai Bentuk Pencegahan Covid-19. Jambura Journal of Health Sciences and Research, 2(2), 65-70. https://doi.org/10.35971/jjhsr.v2i2.6563

Prasetyawati, N. D., Sudaryanto, S., \& Usmaningrum, D. U. (2021). PERAN MEDIA DALAM UPAYA MENINGKATKAN PENGETAHUAN DAN TINDAKAN PENCEGAHAN CORONAVIRUS DISEASE (COVID 19). Jurnal Inovasi Penelitian, 1(8), 1609-1617.

Spinelli, M., Lionetti, F., Pastore, M., \& Fasolo, M. (2020). Parents' Stress and Children's Psychological Problems in Families Facing the COVID-19 Outbreak in Italy. Frontiers in Psychology, 11(July), 1-7. https://doi.org/10.3389/fpsyg.2020.01713

Sprang, G., \& Silman, M. (2013). Posttraumatic stress disorder in parents and youth after health-related disasters. Disaster Medicine and Public Health Preparedness, 7(1), 105-110. https://doi.org/10.1017/dmp.2013.22

Sumakul, Y., \& Ruata, S. C. N. (2020). Kesejahteraan Psikologis dalam masa Pandemi COVID-19. Journal of Psychology "Humanlight," 1(1).

Tremblay, M. S., Carson, V., Chaput, J. P., Connor Gorber, S., Dinh, T., Duggan, M., Faulkner, G., Gray, C. E., Grube, R., Janson, K., Janssen, I., Katzmarzyk, P. T., Kho, M. E., Latimer-Cheung, A. E., LeBlanc, C., Okely, A. D., Olds, T., Pate, R. R., Phillips, A., ... Zehr, L. (2016). Canadian 24-hour movement guidelines for children and youth: An integration of physical activity, sedentary behaviour, and sleep. Applied Physiology, Nutrition and Metabolism, 41(6), S311-S327. https://doi.org/10.1139/apnm2016-0151

Wong, M. C. S., Wong, E. L. Y., Huang, J., Cheung, A. W. L., Law, K., Chong, M. K. C., Ng, R. W. Y., Lai, C. K. C., Boon, S. S., Lau, J. T. F., Chen, Z., \& Chan, P. K. S. (2021). Acceptance of the COVID-19 vaccine based on the health belief model: A population-based survey in Hong Kong. Vaccine, 39(7), 1148-1156. https://doi.org/10.1016/j.vaccine.2020.12.083

World Health Organization. (2020). Mental health and psychosocial considerations during the. Mental Health and Psychosocial Consiederations during the COVID- 19 Outbreak, January, 1-6. 